Naskah publikasi skripsi-S1 Roza Oktama (belum diterbitkan)

\title{
KARAKTERISASI AKUIFER KARST MATAAIR NGELENG DENGAN PENDEKATAN VARIASI TEMPORAL SIFAT ALIRAN DAN HIDROGEOKIMIA
}

\author{
Roza Oktama \\ rozamail08@gmail.com \\ Tjahyo Nugroho Adji \\ adji@geo.ugm.ac.id
}

\begin{abstract}
Flow properties and hydrogeochemistry is the main approach in this study. The purpose of this study was to determine the temporal variation of the Ngeleng Spring karst aquifer flow properties, examines the temporal variation of Ngeleng Spring karst aquifers hydrogeochemistry, and to study the relationship between the flow properties and hydrogeochemistry of Ngeleng Spring. Research method in this study classified as a field survey using data such as water level, discharge, and water chemical contents. Sampling was divided into long-term sampling and flood event sampling. The analysis that used in this study is a graphical analysis, scatter plot analysis, and descriptive analysis. The results of recession constant analysis stated that the flow component of Ngeleng springs dominated by diffuse component. Determination between flow properties and hydrogeochemistry states that on rainy season occured rain water mixing process, then on dry season occur the domination of water interaction with the aquifer material, as well as the diffusion transfer process because of the spring open system. Calcite aggressivity on rainy season are tends to the unsaturated phase, while in the dry season tends to the equilibrium phase.
\end{abstract}

Keyword : $\quad$ karst aquifer, flow properties, hydrogeochemistry

\begin{abstract}
ABSTRAK
Sifat aliran dan hidrogeokimia adalah pendekatan utama dalam penelitian ini. Tujuan dari penelitian ini adalah mengetahui variasi temporal sifat aliran akuifer karst Mataair Ngeleng, mengkaji variasi temporal hidrogeokimia akuifer karst Mataair Ngeleng, dan mempelajari hubungan antara sifat aliran dengan hidrogeokimia Mataair Ngeleng. Metode dalam penelitian tergolong sebagai survei lapangan dengan data berupa tinggi muka air, debit, dan kandungan unsur kimia air. Pengambilan sampel terbagi atas atas sampel jangka panjang dan sampel kejadian banjir. Analisis yang digunakan dalam penelitian ini adalah analisis grafis, analisis scatter plot, dan analisis deskriptif. Hasil analisis konstanta resesi menyatakan bahwa komponen aliran Mataair Ngeleng didominasi oleh komponen aliran diffuse. Hubungan variasi temporal sifat aliran dan hidrogeokimia menyatakan bahwa pada musim penghujan terjadi proses percampuran dengan air hujan, kemudian pada periode musim kemarau didominasi proses interaksi air dengan material akuifer, serta proses difusi karena adanya sistem terbuka. Agresivitas terhadap mineral kalsit pada musim penghujan berada pada fase tidak jenuh, sedangkan pada periode musim kemarau cenderung pada fase setimbang.
\end{abstract}

Kata kunci : akuifer karst, sifat aliran, hidrogeokimia 


\section{PENDAHULUAN}

Sistem hidrologi karst memiliki karakter tersendiri dengan adanya dominasi proses pembentukan non-permukaan (Haryono dan Adji, 2004; Haryono et al, 2009; Adji, 2005; Adji dan Hariadi, 2009; Adji and Misqi, 2010). Dengan kata lain, hasil proses pelarutan mengakibatkan minimnya aliran permukaan dan lebih berkembangnya sistem aliran bawah permukaan dengan sifat tidak seragam (heterogen) dan anisotropis yang kemudian diklasifikasikan oleh White (1988) menjadi sistem aliran rembesan (diffuse), sistem aliran rekahan (fissure), dan sistem aliran lorong (conduit). Ford dan Williams (1989) turut menjabarkan bahwa bentanglahan karst tersusun oleh kombinasi batuan yang mudah larut dan perkembangan porositas sekunder yang tinggi, sehingga sistem hidrologi karst memiliki keistimewaan berupa dominasi proses pembentukan aliran bawah permukaan. Lebih jauh bicara mengenai proses pembentukan bentuklahan karst atau juga dikenal juga dengan proses karstifikasi yang berupa interaksi antara airtanah dan mineral karbonat penyusun batuan dengan proses utama berupa pelarutan (dissolution) memberikan pengaruh terhadap komposisi kimia airtanah di kawasan karst (Appelo and Postma, 1994; Bogli, 1980; Adji, 2013; Adji 2014; Adji 2010; Adji, 2011; Adji, 2015).).

Secara praktis penentuan Mataair Ngeleng sebagai objek dalam karakterisasi akuifer karst dilakukan dengan alasan bahwa mataair adalah keluaran atau luahan air dari suatu sistem akuifer yang terbentuk akibat adanya gerakan airtanah pada celah-celah batuan (White, 1988), sehingga air yang keluar dari suatu mataair dianggap sesuai untuk merepresentasikan karakter akuifer karst. Ditinjau dari sisi manfaat, Mataair Ngeleng, Kawasan Karst Gunungsewu atau secara administratif terletak di Kecamatan Purwosari memiliki fungsi sebagai satu-satunya sumber utama air yang memiliki kelebihan berupa kualitas air yang relatif baik, terdapat di permukaan sehingga cenderung lebih mudah untuk didistribusikan, dan mengalir sepanjang tahun. Bentuk pemanfaatan Mataair Ngeleng adalah untuk pemenuhan kebutuhan air domestik dan irigasi andalan bagi empat dusun yaitu Dusun Petoyan, Dusun Susukan, Dusun Nglegok, dan Dusun Tompak. Namun dibalik manfaat Mataair Ngeleng, masih sangat sedikit penelitian mengenai karakter mataair, sehingga judul penelitian ini dianggap penting untuk dilaksanakan oleh penyusun.

Tujuan dari penelitian ini adalah mengetahui variasi temporal sifat aliran akuifer karst Mataair Ngeleng, mengkaji variasi temporal hidrogeokimia akuifer karst Mataair Ngeleng, dan mempelajari hubungan antara sifat aliran dengan hidrogeokimia Mataair Ngeleng.

\section{METODE PENELITIAN}

Pendekatan yang digunakan dalam penelitian ini adalah pendekatan deduktif karena fokus penelitian dilakukan terhadap hasil proses atau produk dari kerja suatu sistem berupa air yang mengalir keluar dari mataair yang merepresentasikan karakteristik akuifer karst.

Data yang digunakan dalam penelitian ini berupa data hasil pengukuran langsung di lapangan, hasil pencatatan otomatis, dan hasil uji di laboratorium berupa data tinggi muka air untuk mengetahui fluktuasi aliran dan sebagai bahan untuk pembuatan rating curve, data debit untuk menentukan sifat aliran, dan data kandungan unsur kimia air.

Lebih spesifik dengan mengacu pada Currens (1999) yang telah meneliti seberapa efektif data yang dihasilkan dari beberapa teknik pengambilan sampel yang bervariasi berdasarkan waktu pengambilan, maka pengambilan sampel kimia air yang dilakukan dalam penelitian ini terbagi atas atas sampel 
Naskah publikasi skripsi-S1 Roza Oktama (belum diterbitkan)

jangka panjang dengan interval waktu pengambilan 2 mingguan dan sampel berdasarkan kondisi debit aliran saat kejadian banjir (flood discharge sampling)

Tahap pengolahan data dilakukan dengan perhitungan terhadap hasil pencatatan tinggi muka air otomatis untuk dirubah menjadi hidrograf dengan persamaan rating curve, kemudian dilanjutkan dengan perhitungan konstanta resesi menggunakan persamaan oleh Schulz (1976) sebagai berikut.

Keterangan:

$$
\mathrm{Q}_{\mathrm{t}}=\mathrm{Q}_{0} \mathrm{Kr}
$$

$\mathrm{Q}_{\mathrm{t}} \quad$ : Debit aliran pada waktu $\mathrm{t}$

$\mathrm{Q}_{0} \quad$ : Debit awal pada segmen resesi

$\mathrm{Kr} \quad$ : Konstanta resesi

Setelah diperoleh nilai konstanta resesi dilanjutkan dengan perhitungan persentase aliran dasar dengan pendekatan matematis metode automated base flow separation by digital filtering (Eckhardt, 2005), yaitu mencari nilai digital filtering atas dasar nilai konstanta resesi aliran dasar pada hidrograf sepanjang tahun yang kemudian dihubungkan dengan nilai indeks aliran dasar maksimum $\left(\mathrm{BFI}_{\max }\right)$ di akuifer karst dengan rumus sebagai berikut:

$$
q_{b(i)}=\frac{\left(1-B F I_{\max }\right) a q_{b(i-1)}+(1-a) B F I_{\max } q_{i}}{1-a B F I_{\max }}
$$

Keterangan:

$\begin{array}{ll}\mathrm{q}_{\mathrm{b}(\mathrm{i})} & \text { : Aliran dasar pada waktu i } \\ \mathrm{q}_{\mathrm{b}(\mathrm{i}-1)} & : \text { Aliran dasar pada watu i-1 } \\ \alpha & : \text { Konstanta resesi baseflow } \\ \alpha \mathrm{BFI}_{\max } & : \text { Aliran dasar maksimum terukur }\end{array}$

Pengolahan data kandungan kimia air dimulai dengan perhitungan charge balance error dan ditentukan tipe kimia airtanah yang dimiliki dengan Klasifikasi SzczukariewPriklonski (Jankowski, 2002). Perangkat lunak NETPATH 2.3.1 kemudian digunakan untuk menentukan $\log \mathrm{PCO}_{2}$ dan indeks kejenuhan kalsit. Tahap akhir dari penelitian ini adalah uji scatter plot antara parameter sifat aliran dengan beberapa parameter hidrogeokimia untuk mengetahui keberadaan hubungan antara keduanya diikuti analisis grafis dan analisis deskriptif dalam menjabarkan karakter akuifer karst Mataair Ngeleng.

\section{DESKRIPSI DAERAH PENELITIAN}

Secara absolut Mataair Ngeleng terletak pada koordinat 49M $431715 \mathrm{mT}, 9115928 \mathrm{mU}$ dan Secara administratif terletak di Desa Giritirto, Kecamatan Purwosari, Kabupaten Gunungkidul.

Berdasarkan kondisi iklimnya, suhu udara di Desa Giritirto berkisar antara $24,4^{\circ} \mathrm{C}$ sampai $25,9^{\circ} \mathrm{C}$ dengan curah hujan rata-rata bulanan yang disajikan pada grafik di Gambar 1 berikut.

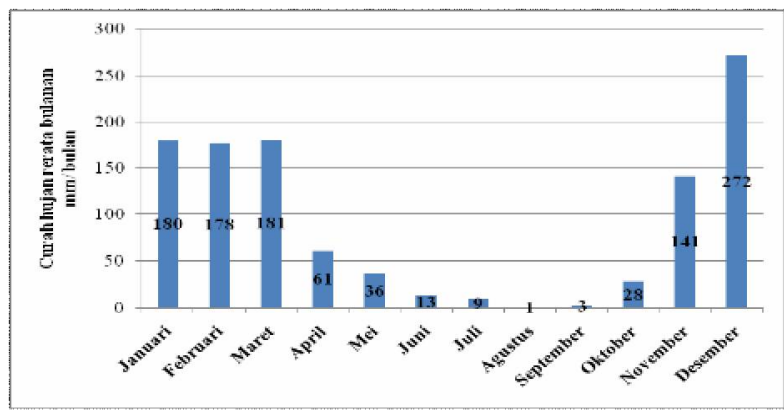

Gambar 1. Curah Hujan Rata-rata Bulanan

Desa Giritirto (Hasil Perhitungan, 2013)

Secara umum pola curah hujan rata-rata bulanan di Desa Giritirto dengan nilai yang tinggi terjadi pada bulan Januari hingga Maret dan bulan November hingga Desember, sedangkan curah hujan rata-rata bulanan dengan nilai yang rendah terjadi pada bulan April hingga Oktober.

Kondisi geologi Desa Giritirto dicirikan melalui dua fisiografi berupa Perbukitan Struktural Baturagung di bagian utara dan Kawasan Karst Gunungsewu yang mengindikasikan keberadaan Formasi Nglanggran dan Formasi Wonosari, dimana 
keberadaan dominasi Formasi Wonosari Adji et al, 2009; Adji et al, 2007; Adji and Rahmawati, 2010; Hariadi dan Adji, 2009) menandakan bahwa material batugamping adalah material yang menyusun akuifer Mataair Ngeleng. Ditinjau dari kondisi hidrogeologi, Desa Giritirto termasuk ke dalam Sub-sistem Panggang (Kusumayudha, 2005) dengan elevasi antara $0 \mathrm{~m}$ hingga $300 \mathrm{~m}$, tidak memiliki aliran permukaan, tebal akuifer antara $50 \mathrm{~m}$ hingga $100 \mathrm{~m}$ dengan dominasi jenis akuifer bebas (unconfined aquifer), serta luahan melalui mataair permukaan dengan debit terbilang kecil ( <100 liter/detik). Seperti halnya Mataair Ngeleng yang selama rentang waktu penelitian pada bulan Desember 2012 hingga bulan Juli 2013 memiliki debit berkisar antara 5,6-48,5 liter/detik.

\section{HASIL DAN PEMBAHASAN}

Sifat aliran akuifer karst Mataair Ngeleng berdasarkan hidrograf aliran pada Gambar 2 selama rentang waktu penelitian (Desember 2012-Juli 2013) menunjukan debit terendah adalah sebesar 5,5 liter/detik dan debit tertinggi adalah sebesar 48,4 liter/detik.

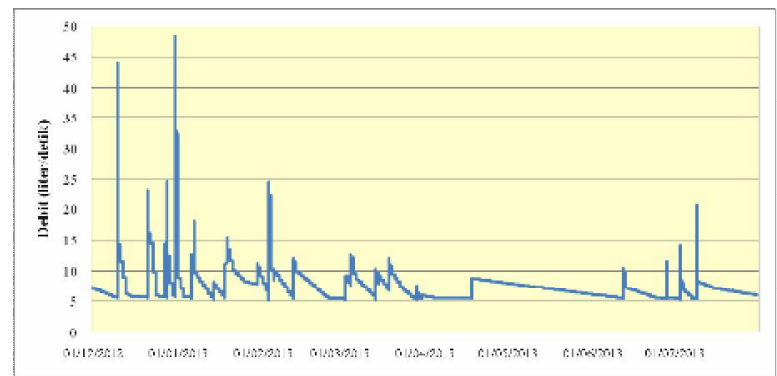

Gambar 2. Hidrograf Aliran Mataair Ngeleng Periode Bulan Desember 2012-Juli 2013

(Hasil Analisis, 2013)

Perhitungan konstanta resesi menunjukkan hasil sebagai berikut: rata-rata konstanta resesi aliran diffuse (Kb) sebesar 0,9844; rata-rata nilai konstanta resesi aliran fissure (Ki) sebesar 0,4636; dan rata-rata konstanta resesi aliran conduit (Kc) sebesar 0,0716. Nilai konstanta resesi tersebut menandakan bahwa komponen aliran Mataair Ngeleng didominasi oleh komponen aliran diffuse selama rentang waktu penelitian. Urutan pelepasan komponen aliran Mataair Ngeleng dari yang paling awal adalah komponen aliran conduit, komponen aliran fissure, kemudian komponen aliran diffuse. Parameter hidrograf berupa time to peak memiliki rata-rata selama 3,6 jam menjadi bukti terdapatnya komponen fissure dan komponen conduit.

Persentase aliran dasar bulanan selama rentang waktu penelitian berkisar pada $80 \%$ dan sesuai dengan hasil perhitungan konstanta resesi bahwa aliran didominasi oleh komponen aliran diffuse seperti yang dapat diamati dalam Gambar 3 berikut.

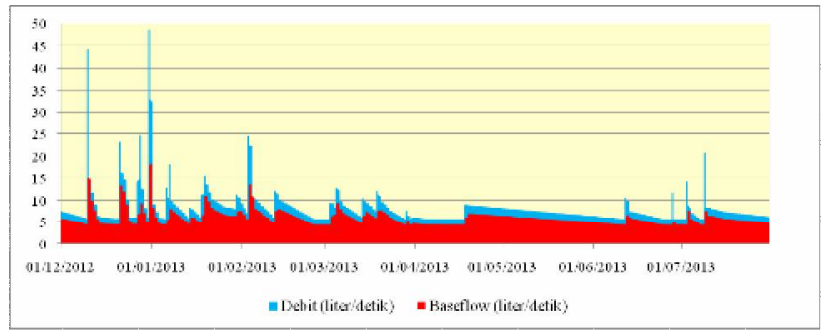

Gambar 3. Fluktuasi Debit dan Baseflow aliran Mataair Ngeleng Periode Bulan Desember 2012 - Juli 2013 (Hasil Analisis, 2013)

Hubungan antara debit dengan persentase aliran dasar saat kejadian banjir menunjukan variasi tingkat determinasi yang disebabkan oleh fluktuasi debit dan persentase aliran dasar yang berbeda-beda pada tiap periode. Determinasi paling rendah terjadi pada periode puncak musim hujan, kemudian diikuti oleh kejadian banjir pada periode akhir musim hujan, lalu determinasi paling tinggi dimiliki oleh kejadian banjir pada periode musim kemarau.

Hidrogeokimia Mataair Ngeleng memiliki tipe kimia air $\mathrm{HCO} 3-\mathrm{Ca}$ berdasarkan Klasifikasi Szczukariew-Priklonski yang berarti air terbukti berasal dari sistem akuifer karst yang tersusun atas material batugamping dengan mineral kalsit serta memiliki unsur terlarut dominan berupa kalsium dan bikarbonat. Hidrokemograf selama rentang waktu penelitian 
(Desember 2012-Juli 2013) menunjukan keberadaan dua pola pengelompokan yakni pola pengelompokan pada periode musim penghujan dan pola pengelompokan pada periode musim kemarau. Pola fluktuasi daya hantar listrik dan kandungan unsur terlarut dominan serupa dengan fluktuasi persentase aliran dasar yang berarti terdapat pengaruh dari keberadaan komponen diffuse yang telah mengalami proses interaksi antara air dengan material penyusun akuifer, sedangkan pola fluktuasi $\mathrm{pH}$ dan $\log$ $\mathrm{PCO}_{2}$ serupa dengan fluktuasi debit yang berarti lebih dipengaruhi oleh proses percampuran dengan air hujan.

Variasi temporal agresivitas Mataair Ngeleng terhadap mineral kalsit pada periode musim penghujan berfluktuasi pada nilai indeks kejenuhan 1,1 hingga 0,1 yang berarti masih berkisar pada fase tidak jenuh (unsaturated), kemudian pada periode musim kemarau nilai indeks kejenuhan berfluktuasi pada kisaran -0,2 hingga $-0,4$ yang berarti berada dalam fase tidak jenuh (unsaturated) namun lebih dekat dengan kisaran fase setimbang (equilibrium). Variasi temporal indeks kejenuhan kalsit disajikan pada Gambar 4.

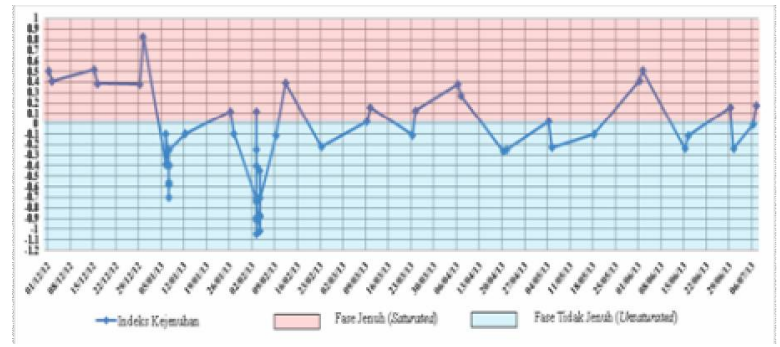

Gambar 4. Fluktuasi Nilai Indeks Kejenuhan Kalsit Mataair Ngeleng Pada Periode Desember 2012 - Juli 2013 (Hasil Analisis, 2013)

Pengaruh $\log \mathrm{PCO}_{2}$ dan $\mathrm{pH}$ terhadap indeks kejenuhan kalsit baik pada periode musim penghujan maupun pada periode musim kemarau bersifat negatif dengan determinasi yang kuat, seperti yang dapat diamati pada Gambar 5 dan Gambar 6.

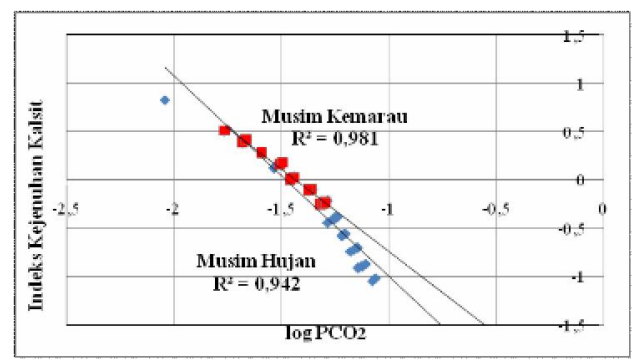

Gambar 5. Scatter Plot log $\mathrm{PCO}_{2}$ dengan Indeks Kejenuhan Kalsit Mataair Ngeleng

(Hasil Analisis, 2013)

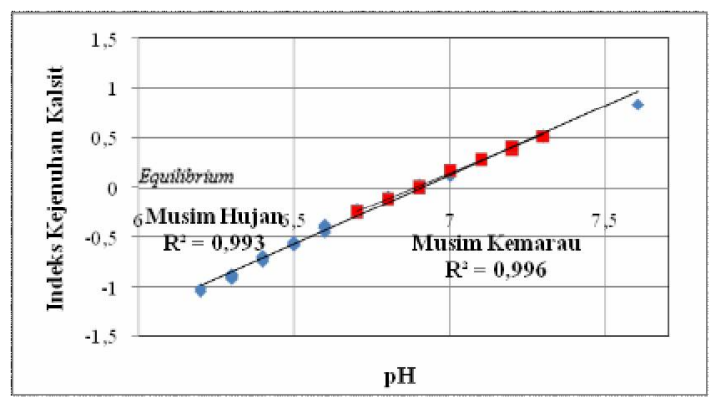

Gambar 6. Scatter Plot log $\mathrm{pH}$ dengan Indeks Kejenuhan Kalsit Mataair Ngeleng

(Hasil Analisis, 2013)

Determinasi kuat dari log $\mathrm{PCO}_{2}$ dan $\mathrm{pH}$ terhadap indeks kejenuhan kalsit terjadi karena pada periode musim penghujan terjadi proses percampuran dengan air hujan, kemudian pada periode musim kemarau terdapat sisa komponen aliran yang telah mengalami proses percampuran dengan air hujan dan juga terdapat pengaruh dari kondisi terbuka Mataair Ngeleng.

Hubungan antara sifat aliran dengan kondisi hidrogeokimia Mataair Ngeleng yang pertama adalah debit dengan kandungan unsur terlarut dominan yang memiliki hubungan negatif dengan determinasi sedang-kuat pada periode musim penghujan maupun musim kemarau yang menandakan adanya penambahan komponen aliran conduit merubah kandungan unsur terlarut dominan. Hubungan debit dengan $\log \mathrm{PCO}_{2}$ dengan scatter plot pada Gambar 7 menunjukan hubungan positif dengan determinasi pada musim penghujan lebih tinggi dibandingkan dengan determinasi pada musim 
kemarau. Hal tersebut terjadi karena pada musim penghujan terjadi proses percampuran dengan air hujan yang memasok gas $\mathrm{CO}_{2}$ dalam jumlah besar, sedangkan pada musim kemarau pasokan gas $\mathrm{CO}_{2}$ hanya berasal dari transfer difusi karena kondisi aliran terbuka (open system) milik Mataair Ngeleng.

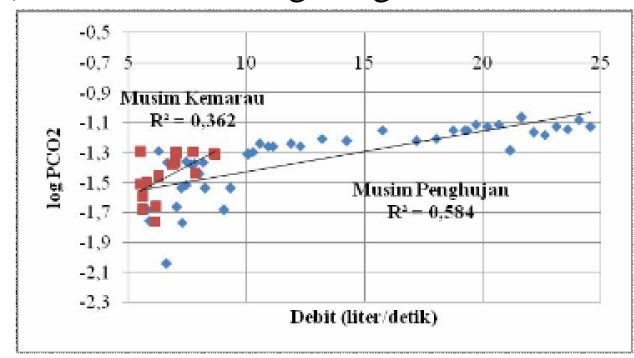

Gambar 7. Scatter Plot Debit dengan log $\mathrm{PCO}_{2}$ Mataair Ngeleng (Hasil Analisis, 2013)

Hubungan antara persentase aliran dasar dengan kandungan unsur terlarut dominan adalah hubungan positif dengan determinasi sedang yang berarti perubahan persentase aliran dasar mempengaruhi kandungan unsur terlarut dominan karena adanya penambahan komponen aliran baik fissure maupun conduit. Pada musim penghujan terjadi pengaruh yang sama dengan periode musim penghujan namun terdapat anomali pada nilai koefisien determinasi yang sangat kecil yang diduga terjadi karena keterbatasan jumlah sampel. Pengaruh persentase aliran dasar terhadap log $\mathrm{PCO}_{2}$ pada musim hujan maupun musim kemarau terbilang lemah menandakan bahwa kandungan gas $\mathrm{CO}_{2}$ lebih dipengaruhi oleh pasokan yang berasal dari campuran dengan air hujan dan transfer difusi. Pengaruh dari kandungan unsur terlarut dominan terhadap daya hantar listrik terjadi karena adanya proses interaksi air dengan batuan penyusun akuifer Mataair Ngeleng sehingga ion yang mempengaruhi daya hantar listrik berasal dari kandungan unsur terlarut dominan berupa kalsium dan bikarbonat.

Hubungan ion natrium dan klorida pada scatter plot dengan garis rasio 1:1 pada Gambar 8 menunjukan bahwa sampel yang dikumpulkan selama rentang waktu penelitian didominasi oleh sampel dalam periode musim penghujan dibandingkan sampel periode musim kemarau, serta dapat dibuktikan bahwa telah terjadi proses percampuran dengan air hujan yang mempengaruhi kondisi hidrogeokimia Mataair Ngeleng.

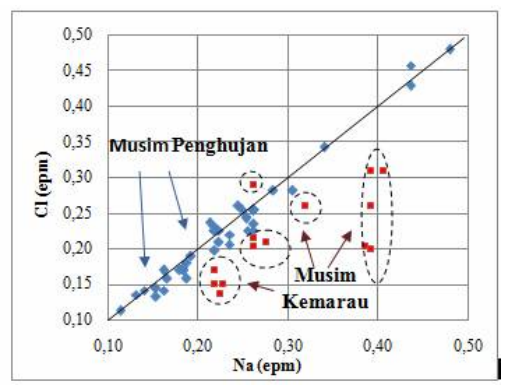

Gambar 8. Scatter Plot dengan Garis Rasio 1:1 Antara Kandungan Natrium dan Kandungan Klorida (Hasil Analisis, 2013)

\section{KESIMPULAN}

Berdasarkan hasil analisis konstanta resesi, dinyatakan bahwa komponen aliran Mataair Ngeleng didominasi oleh komponen aliran diffuse selama rentang waktu penelitian. Persentase aliran dasar bulanan selama rentang waktu penelitian berkisar pada $80 \%$ dan sesuai dengan hasil perhitungan konstanta resesi bahwa aliran didominasi oleh komponen aliran diffuse.

Hidrogeokimia Mataair Ngeleng memiliki tipe kimia air $\mathrm{HCO}_{3}-\mathrm{Ca}$ dengan unsur terlarut dominan berupa kalsium dan bikarbonat. Hidrokemograf selama rentang waktu penelitian menunjukan variasi temporal daya hantar listrik dan kandungan unsur terlarut dominan serupa dengan fluktuasi persentase aliran dasar yang menandakan terdapat pengaruh komponen aliran diffuse yang telah mengalami proses interaksi antara air dengan material penyusun akuifer. Variasi temporal $\mathrm{pH}$ dan $\log \mathrm{PCO}_{2}$ serupa dengan fluktuasi debit yang berarti lebih dipengaruhi oleh proses percampuran dengan air hujan. Variasi temporal agresivitas Mataair Ngeleng terhadap mineral kalsit pada periode musim penghujan berkisar pada fase tidak jenuh (unsaturated), kemudian pada periode musim 
kemarau nilai indeks kejenuhan lebih dekat dengan kisaran fase setimbang (equilibrium).

Hubungan debit dengan log $\mathrm{PCO}_{2}$ merupakan hubungan positif dengan determinasi pada musim penghujan lebih tinggi dibandingkan dengan determinasi pada musim kemarau karena pengaruh dari proses percampuran dengan air hujan yang memasok gas $\mathrm{CO}_{2}$. Hubungan antara persentase aliran dasar dengan kandungan unsur terlarut dominan adalah hubungan positif dengan determinasi sedang yang berarti perubahan persentase aliran dasar mempengaruhi kandungan unsur terlarut dominan. Pengaruh kuat dari kandungan unsur terlarut dominan terhadap daya hantar listrik terjadi karena adanya proses interaksi air dengan batuan penyusun akuifer Mataair Ngeleng sehingga terdapat ion kalsium dan bikarbonat yang mempengaruhi daya hantar listrik. Rasio perbandingan 1:1 antara kandungan ion natrium dengan ion klorida menunjukan bahwa sampel yang dikumpulkan selama rentang waktu penelitian didominasi oleh sampel dalam periode musim penghujan, serta dapat dibuktikan bahwa telah terjadi proses percampuran dengan air hujan.

\section{DAFTAR PUSTAKA}

Adji, T. N. 2011. Pemisahan Aliran Dasar Bagian Hulu Sungai Bribin pada Aliran Gua Gilap, di Kars Gunung Sewu, Gunung Kidul, Yogyakarta. Jurnal Geologi Indonesia, Vol 6 No. 3, Hal. 165-175.

Adji, T. N., 2010. Spatial and Temporal Variation of Hydrogeochemistry and Karst Flow Properties to Characterize Karst Dynamic System in Bribin Underground River, Gunung Kidul Regency, DIY Province Java, Indonesia. Summary, Dissertation in Geography Study Program. Graduate School of Geography, Gadjah Mada University, Yogyakarta

Adji, T. N., 2010. Variasi Spasial-Temporal Hidrogeokimia dan Sifat Aliran Untuk Karakterisasi Sistem Karst Dinamis Di Sungai Bawah Tanah Bribin, Kabupaten Gunungkidul, DIY. Disertasi. Fakultas Geografi, Universitas Gadjah Mada.
Adji, T. N., et al. 2006. The Distribution Of Flood Hydrograph Recession Constant Of Bribin River For Gunung Sewu Karst Aquifer Characterization. Dipublikasi ulang dari Gunung Sewu-Indonesian Cave and Karst Journal (Vol. 2. No.2)

Adji, T.N. 2012, Wet Season Hydrochemistry of Bribin River in Gunung Sewu Karst, Indonesia, Environmental Earth Sciences, Vol. 67:1563$1572 \mathrm{pp}$

Adji, T.N. dan Haryono, E., 1999. Konflik Antara Pemanfaatan Batugamping dan Konservasi Sumberdaya Air Das Bribin di Wilayah Karst Gunung Sewu, Makalah Lokakarya Nasional Menuju Pengelolaan Sumberdaya Wilayah Berbasis Ekosistem Untuk Mereduksi Konflik Antar Daerah, Yogjakarta, , Fakultas Geografi, Universitas Gadjah Mada, September 1999

Adji, T.N., 2005, Agresivitas Airtanah Karst Sungai Bawah Tanah Bribin, Gunung Sewu, Indonesian Cave and Karst Journal, Vol. 1 No1, HIKESPI

Adji, T.N., 2011, Upper catchment of Bribin underground river hydrogeochemistry (Gunung Sewu Karst, Gunung Kidul, Java, Indonesia) Proceeding of Asian Trans-Disclipinary Karst Conference, Yogyakarta

Adji, T.N., 2013, Hubungan Karakter Aliran dan Sifat Kimia Mataair Petoyan Untuk Karakterisasi Akuifer Karst, Hibah Dana Masyarakat Fak. Geografi UGM

Adji, T.N., Haryono, E., Woro, S, 1999, Kawasan Karst dan Prospek Pengembangannya di Indonesia, Seminar PIT IGI di Universitas Indonesia, 26-27 Oktober 1999

Adji, T.N., Hendrayana, H., Sudarmadji, dan Suratman, W., 2009. Diffuse Flow Separation Within Karst Underground River At Ngreneng Cave. Proceeding of International Conference Earth Science and Technology, 6-7 Aug, Yogyakarta.

Adji, T.N., Misqi, M., 2010, The Distribution of Flood Hydrograph Recession Constant for Characterization of Karst Spring and Underground River Flow Components Releasing Within Gunung Sewu Karst Region, Indonesian Journal of Geography, XLII(1)

Adji, T.N., Rahmawati, N., 2010, The Contribution of $\mathrm{CO}_{2}$ Content in Rainfall to Dissolution Process in Karst Area (Case Study In Bribin Underground River), The Proceeding of Technology cooperation and economic benefit of reduction of GHG emissions in Indonesia" held on 1-2 November 2010 in Hamburg

Adji, T.N., Sudarmadji, Suprojo, S.W., Hendrayana, 
Naskah publikasi skripsi-S1 Roza Oktama (belum diterbitkan)

H., Hariadi, B., 2007. The Distribution of Flood Hydrograph Recession Constant of Bribin River for Gunung Sewu Karst Aquifer Characterization, Proceeding of International Symposium on Earth Resources and Geological Engineering Educational , 17-18 Dec 2007, Jogjakarta

Appelo, C.A.J., Postma, D., 1994. Geochemistry, Groundwater and Pollution. A.A. Balkema.

Bogli. 1980. Karst Hydrology and Physical Speleology. Springer. Verlag.

Currens, J., C. A Sampling Plan For Conduit Flow Karst Springs, Minimizing Sampling Cost and Maximizing Statistical Utility, Engineering Geology (52. page 121-128)

Eckhardt K, 2005. How to construct recursive digital filters for baseflow separation. Hydrological Processes 19, 507-515.

Ford, D and Williams, P. 1992. Karst Geomorphology and Hydrology. London: Chapman and Hall.

Hariadi, B., Adji, T.N., 2009, Variasi Temporal Hidrogeokimia Tetesan dari Ornamen Drapery di Dalam Gua Gilap di Kawasan Karst Gunungsewu, Kabupaten Gunungkidul, DIY, Gunung Sewu-Indonesian Cave and Karst Journal, Vol 5 No 1, April 2009

Haryono, E. dan Adji, T.N. 2004. Geomorfologi dan Hidrologi Karst. Yogyakarta : Kelompok Studi Karst Fakultas Geografi UGM.

Jankowski, J. 2002. Groundwater Environment, Short Course Note. Sydney: School of Geology, University of New South Wales.

Schulz, E.F. 1976. Problems in Applied Hydrology. Colorado: Water Resources Publication.

White, W. B. 1988. Geomorphology and Hydrology of Karst Terrains. New York: Oxford University Press. 